\title{
Epidermal Growth Factor and Its Receptor in Bovine Corpus Luteum during the Estrous Cycle
}

\author{
Kiyoshi OKUDA, Yoshihisa UENOYAMA, Kwang-Nam HWANG ${ }^{1, \#,}$ \\ Junzo YAMADA ${ }^{2)}$ and Katsumi WAKABAYASHI) \\ Division of Animal Science and Technology, \\ Faculty of Agriculture, Okayama University, Okayama 700, \\ ${ }^{1)}$ Institute of Endocrinology, Gunma University, Maebashi, Gunma 371, and \\ ${ }^{2)}$ Obihiro University of Agriculture and Veterinary Medicine, \\ Obihiro 080, Japan
}

\begin{abstract}
The epidermal growth factor (EGF) concentration and its binding characteristics in bovine corpus luteum (CL) during the estrous cycle (early: Days 3-5, mid-: 8-12, late stage: 15-18) were determined. The EGF concentrations in corpus luteum tissue, evaluated by a radioreceptor assay using human placenta, were $3.0 \pm 0.7 \mathrm{ng} / \mathrm{g}$ in early luteal phase, $43.9 \pm 2.2 \mathrm{ng} / \mathrm{g}$ in mid-luteal phase and $18.6 \pm 2.7 \mathrm{ng} / \mathrm{g}$ in late luteal phase. Specific EGF receptors were present in bovine corpus luteum of all luteal phases. TGF $\alpha$, but not IGF-I, FGF and NGF competitively displaced EGF binding. The binding affinity of luteal EGF receptors differed between the luteal stages and decreased significantly from early $(\mathrm{Kd}=0.8 \pm 0.04 \mathrm{nM})$ to mid-luteal stage $(\mathrm{Kd}=1.6 \pm 0.34 \mathrm{nM}$, $\mathrm{P}<0.05)$. The binding capacity of luteal EGF receptor at different luteal stages were similar (early stage; $B \max =35.1 \pm 5.7 \mathrm{fmol} / \mathrm{mg}$ protein, mid-luteal stage; $B \max =46.3 \pm 4.0 \mathrm{fmol} / \mathrm{mg}$ protein, late stage; $B \max =35.1 \pm 5.7 \mathrm{fmol} / \mathrm{mg}$ protein, all values mean $\pm \mathrm{SEM}$ ). These results suggest that $E G F$ plays a physiological role for the regulation of luteal function during the estrous cycle.

Key words: Bovine, Corpus luteum, EGF, EGF receptor, Estrous cycle.
\end{abstract}

(J. Reprod. Dev. 40 : 349-354, 1994)

$\mathbf{E}^{\mathrm{P}}$ pidermal growth factor (EGF) is a 53-residue acidic polypeptide (molecular weight 6045 daltons) which stimulates the proliferation of bovine, porcine, human and rodent granulosa cells [1-4]. Aside from its mitogenic property, it is well demonstrated that EGF modulates several gonadotropin-related functions of granulosa cells; EGF inhibits follicle-stimulating hormone (FSH)-induced estrogen production by cultured rat granulosa cells [5] and FSH-mediated induction of luteinizing hor-

Accepted for Publication: June 23, 1994

Correspondence to : K. Okuda

\#Current address: Department of Veterinary Science, Chungpuk National University, Gaesin-Dong, Cheongju 360763, Korea mone receptors on rat granulosa cells [6]. The granulosa cells differentiate into luteal cells following ovulation, and the number of receptors for EGF on bovine luteal cells increases by severalfold compared to that on granulosa cells [1]. However, EGF does not exhibit any mitogenic effect on luteal cells $[1,7,8]$. Budnik and Mukhopadhyay [9] demonstrated that EGF regulates luteal adenylate cyclase activity, since both basal and forskolin-stimulated adenylate cyclase activity was increased by severalfold, when luteal cells obtained from cows at mid-luteal stage were preincubated with EGF.

It is well demonstrated that the productivity of oxytocin [10] and prostaglandins [11, 12] in bovine 
corpus luteum changes during the estrous cycle. Furthermore, since the luteal receptor concentrations for oxytocin [13] and prostaglandins [14] change during the estrous cycle, it is assumed that these substances play a physiological role in the corpus luteum as an autocrine or paracrine regulator. Although there are several reports describing the presence of receptors for EGF in bovine corpus luteum in pregnancy $[1,8,15]$, no systemic studies available on the expression of EGF or its receptors in bovine corpus luteum during the estrous cycle.

In the present study, therefore, the amounts of EGF and the characteristics of EGF receptors in corpus luteum during the estrous cycle were determined.

\section{Materials and Methods}

\section{Bovine corpora lutea and human placenta}

Ovaries with corpus luteum from Holstein-Fresian cows were collected at a local slaughterhouse within 10-20 min after slaughter. The luteal phase was classified to early (3-5 days after ovulation), mid- (8-12 days after ovulation) and late (15-18 days after ovulation) stages by macroscopic observation of the ovary as described previously [16, 17]. After determination of the stages at the slaughterhouse, the corpora lutea were separated immediately from the ovaries, frozen rapidly in liquid nitrogen and then stored at $-80 \mathrm{C}$ until processed.

Human placenta was obtained just after a spontaneous delivery from a woman who given an informed consent at the Department of Obstetrics and Gynecology, Gunma University School of Medicine. Placenta was washed well with ice-cold isotonic phosphate-buffered saline $(10 \mathrm{mM}$-phosphate buffer, pH 7.4 in $0.15 \mathrm{M}$-sodium chloride; PBS) to remove blood. Chorionic villus tissue was dissected from several different regions of the center of the placental plate, taking care to avoid connective tissue and blood vessels, and stored at $-80 \mathrm{C}$ until processed.

\section{Growth factors}

Rat EGF (rEGF) was prepared from male rat submandibular glands by the methods of Savage and Cohen [18]. Other growth factors were obtained from the following sources: human insulin-like growth factor I (hIGF-I) and human basic fibro- blast growth factor (hbFGF) from Boehringer Mannheim Yamanouchi, Tokyo, Japan; human EGF (hEGF) from Wakunaga Pharm, Hiroshima, Japan; human nerve growth factor (hNGF) and human transforming growth factor $\alpha$ (hTGF $\alpha$ ) from Biomedical Technologies, Inc., Massachusetts, USA.

\section{Membrane preparation}

Corpora lutea and placenta villi were thawed at room temperature and minced with scissors in icecold $25 \mathrm{mM}$-Tris-HCl-buffer containing 0.3 M-sucrose, 2 mM-EDTA, 3 mM-dithiothreitol (Sigma Chemical Co., St. Louis, MO, USA), aprotinin (500 KIU/ml, Sigma) and $0.5 \mathrm{mM}$-phenylmethylsulfonyl fluoride (PMSF, Sigma), pH 7.4, and then homogenized in the same buffer with Polytron homogenizer (Kinematica, Lucerne, Switzerland) using two 10-sec bursts at full speed, separated by a 1-min cooling period in ice. For each luteal stage, three pools were prepared with each containing homogenates derived from 5 corpora lutea. The homogenates of luteal and placental tissue were subsequently centrifuged at $800 \mathrm{~g}$ for $10 \mathrm{~min}$ at 4 C. The supernatant including cell membranes was collected and centrifuged at 20,000 g for $20 \mathrm{~min}$ at $4 \mathrm{C}$. The pellet was resuspended in $25 \mathrm{mM}$-Tris$\mathrm{HCl}$-buffer, $\mathrm{pH} 7.4$, and centrifuged at 20,000 $\mathrm{g}$ for $10 \mathrm{~min}$ at $4 \mathrm{C}$. This was repeated three times and the final pellet was resuspended in the same buffer. The protein concentrations of the membrane preparations were determined by the method of Lowry et al. [19] using bovine serum albumin (BSA) as a standard. The preparation was diluted to give the protein concentrations of 1 and $5 \mathrm{mg} / \mathrm{ml}$ for placenta villi and luteal membrane, respectively, with $25 \mathrm{mM}$-Tris-HCl-buffer containing $10 \mathrm{mM}$ $\mathrm{MgCl}_{2}$ and $0.5 \%(\mathrm{w} / \mathrm{v})$ BSA, because our preliminary experiments showed enough binding for EGF with these protein concentrations to analyse the binding characteristics (data not shown). After that they were stored in $4 \mathrm{ml}$ aliquots at -80 $C$ until assayed.

\section{Preparation of corpus luteum extracts}

Corpus luteum extracts were prepared to measure the EGF concentration by a radioreceptor assay using human placenta. For each luteal stage, 3 samples were prepared. Each sample consisted of homogenates derived from 5 corpora lutea. The homogenates of luteal tissues obtained using the same procedures as described for membrane prep- 
aration, except that an ice-cold PBS, instead of Trisbuffer, containing aprotinin $(500 \mathrm{KIU} / \mathrm{ml})$, and 0.5 mM-PMSF, $\mathrm{pH} 7.4$, were centrifuged at $20,000 \mathrm{~g}$ for $30 \mathrm{~min}$ at $4 \mathrm{C}$. The supernatant was stored at $-80 \mathrm{C}$ until assayed.

\section{Radioreceptor Assays (RRA)}

rEGF was iodinated with carrier-free $\mathrm{Na}^{125} \mathrm{I}$ by the lactoperoxidase method of Thorell and Johansson [20]. Specific activity of ${ }^{125}$ I-labelled rEGF was measured by self-displacement assay using the membrane preparation obtained from the corpora lutea of mid-stage stored as a standard receptor source, and ranged from 114.7 to $189.0 \mathrm{cpm} / \mathrm{pg}$.

Preliminary studies with mid-luteal and placental membranes were carried out to establish the optimal conditions of incubation-time and temperature for maximal binding of ${ }^{125} \mathrm{I}$-labelled rEGF to the membranes. The assays were performed in triplicate with $0.1 \mathrm{ml}$ membrane homogenate. The homogenate was incubated for 1-4 h at various temperatures after mixing with approximately $200,000 \mathrm{cpm}(0.2 \mathrm{pmol}){ }^{125}$ I-labelled rEGF $(0.1 \mathrm{ml})$ and $0-1000 \mathrm{ng} / \mathrm{ml}$ unlabelled rEGF, hEGF, hTG$\mathrm{F} \alpha$, hIGF-I, hNGF or hbFGF $(0.1 \mathrm{ml})$ in test tubes. All reagents were prepared in $25 \mathrm{mM}$-Tris- $\mathrm{HCl}$ buffer containing $10 \mathrm{mM}-\mathrm{MgCl}_{2}$ (pH 7.4) and 0.5 $\%(\mathrm{w} / \mathrm{v}) \mathrm{BSA}$. Since maximal binding was obtained at $37 \mathrm{C} 1 \mathrm{~h}$ after the start of incubation and remained stable for at least $4 \mathrm{~h}$, all subsequent binding experiments were performed at $37 \mathrm{C}$ for $2 \mathrm{~h}$. The specificity of ${ }^{125}$ I-labelled rEGF binding to the human placental membrane is shown in Fig. 1. Binding of radiolabelled rEGF to human placental membranes was decreased in a dose-dependent fashion by low levels of unlabelled rEGF and hEGF. hTGF $\alpha$ inhibited the ${ }^{125}$ I-labelled rEGF from binding to human placenta membrane with a crossreactivity of $35.7 \%$ to the binding of rEGF. EGF concentrations of all corpus luteum extracts were measured in an assay. Intra-assay coefficient of variation based on 10 replicates was $9.3 \%$.

The incubation was terminated by transferring the tubes into ice-cold water; bound and free tracers were separated by centrifugation at $2,000 \mathrm{~g}$ for $15 \mathrm{~min}$ at $4 \mathrm{C}$. Supernatants were aspirated immediately under vacuum, and the pellets were counted for ${ }^{125} \mathrm{I}$ in a $\gamma$-counter (Pharmacia-Wallac 1282, Commpugamma CS, Turku, Finland) at an efficiency of $82 \%$. Non-specific bindings accounted for $<2 \%$ (human placenta) or $5 \%$ (bovine corpus luteum) of total binding.

All binding data reported are for specific binding obtained from the differences between total and non-specific binding determined in parallel in the presence of excess unlabelled rEGF. The EGF receptor-specific binding to ${ }^{125}$ I-labelled rEGF was analyzed by Scatchard plots [21] for each individual tissue specimen and the respective binding parameters, including the concentration of binding sites (Bmax) and the dissociation constant $(\mathrm{Kd})$ were determined.

\section{Statistical analysis}

The final parameter estimates obtained from three pools of three different luteal stages were analysed by analysis of variance. The significant differences between the different luteal stages were then assessed by Student's $t$-test. Data are expressed as means $\pm \mathrm{SEM}$.

\section{Results}

\section{Specificity of binding}

Fig. 2 shows the displacement curves of ${ }^{125}$ I-labelled rEGF from bovine corpus luteum membrane by various growth factors on corpus luteum membrane at mid luteal stage. The binding was highly specific for rEGF. An approximately 30-fold higher concentration of the hTGF $\alpha$ was necessary to achieve a $50 \%$ displacement of the labelled ligand.

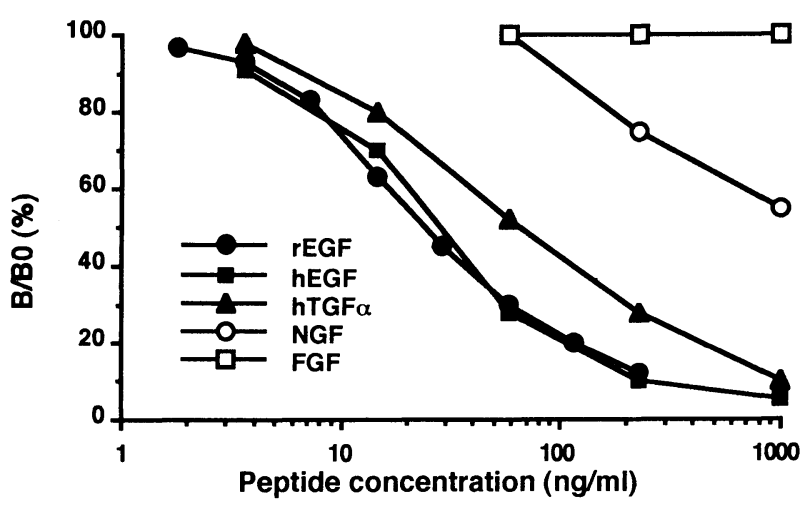

Fig. 1. Specificity of human placental epidermal growth factor (EGF) receptors. Rat EGF (rEGF; ), human EGF (hEGF; $)$, human transforming growth factor$\alpha$ (hTGF $\alpha ; \boldsymbol{\Delta})$, human nerve growth factor (hNGF; O ) and human basic fibroblast growth factor (hbFGF; $\square$ ). 


\section{Specific binding at different luteal stages}

Scatchard plots for the competitive binding of ${ }^{125}$-labelled rEGF and unlabelled rEGF at three different luteal stages were all linear (Fig. 3 A, B, C), thus indicating a single class of high-affinity binding sites. The affinity at mid luteal stage was significantly lower than at early stage $(\mathrm{P}<0.05$, Table $1)$. There is no significant difference in the capacity of binding sites among three luteal stages (Table 1).

\section{EGF concentration in luteal tissue}

As shown in Table 1, the highest concentration of EGF was obtained at mid-luteal stage $(\mathrm{P}<0.001)$. Furthermore the EGF concentration of late luteal

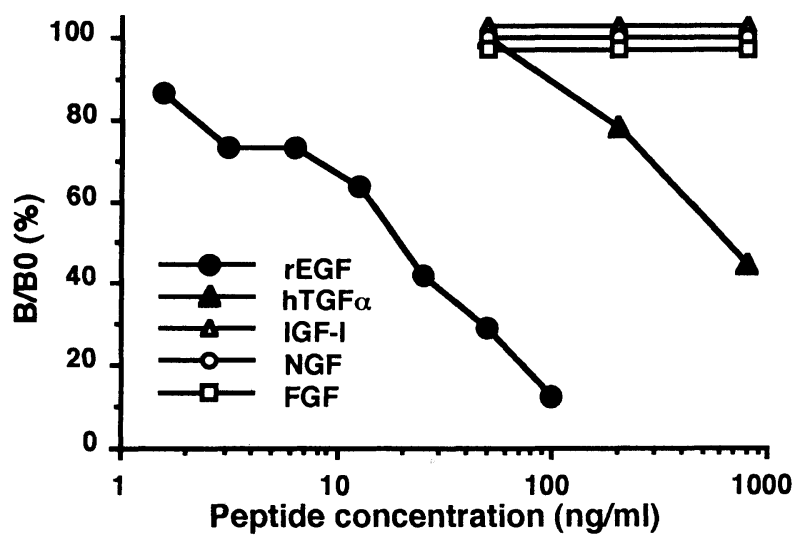

Fig. 2. Competitive binding of ${ }^{125} \mathrm{I}$-labelled rat epidermal growth factor (rEGF) and unlabelled rEGF ( ), human transforming growth factor- $\alpha$ (hTGF $\alpha ; \boldsymbol{\Delta})$, human nerve growth factor (hNGF; $O$ ), human basic fibroblast growth factor (hbFGF; $\square$ ) and human insulin-like growth factor-I (hIGF-I; $\Delta$ ) to the bovine mid-luteal membrane preparation. stage was higher than that of early luteal stage $(\mathrm{P}<0.01)$.

\section{Discussion}

Our study shows the presence of EGF and specific, high-affinity binding sites for ${ }^{125}$ I-labelled rEGF in the bovine corpus luteum of all luteal stages. This suggests that EGF may play a physiological role for the regulation of luteal function during the estrous cycle in cattle.

Membrane fraction of bovine corpus luteum contained single class of high affinity EGF receptors $(\mathrm{Kd}=0.8-1.6 \mathrm{nM})$ at all luteal stages, as observed previously for cultured bovine luteal cells $(\mathrm{Kd}=$ $0.7 \mathrm{nM}$ ) [1]. Although EGF receptors have been
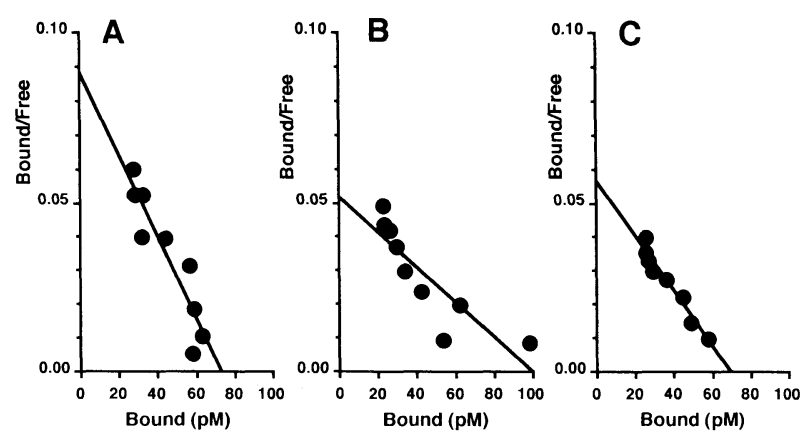

Fig. 3. Scatchard plots of 125 I-labelled rat epidermal growth factor (rEGF) binding to bovine luteal membranes at three different stages of estrous cycle. Binding of 125I-labelled rEGF to luteal membrane preparation at (A) early (days 3-5), (B) mid- (days 8-12) and (C) late (days 15-18) luteal stage.

Table 1. Concentrations of epidermal growth factor (EGF) and binding characteristics of EGF receptor in bovine corpus luteum tissue at three different luteal stages (mean \pm SEM)

\begin{tabular}{lccc}
\hline Luteal stage $^{1}$ & $\begin{array}{c}\text { Concentration of EGF } \\
(\mathrm{ng} / \mathrm{g} \text { tissue })^{2}\end{array}$ & \multicolumn{2}{c}{ Binding characteristics $^{3}$} \\
\cline { 3 - 4 } & $3.0 \pm 0.7^{\mathrm{a}}$ & $0.8 \pm 0.04^{\mathrm{d}}$ & $35.1 \pm 5.7$ \\
\hline Early & $43.9 \pm 2.2^{\mathrm{b}}$ & $1.6 \pm 0.34^{\mathrm{e}}$ & $46.3 \pm 4.0$ \\
Mid- & $18.8 \pm 2.7 \mathrm{c}$ & $1.0 \pm 0.20^{\mathrm{de}}$ & $35.1 \pm 5.7$ \\
Late & & Capacity (Bmax; fmol/mg protein) \\
\hline
\end{tabular}

${ }^{1}$ Early, mid- and late luteal stages are represent 3-5, 8-12 and 15-18 days after ovulation, respectively.

${ }^{2}$ Concentrations of EGF were evaluated by a radioreceptor assay using human placental membranes.

${ }^{3}$ Binding characteristics of EGF receptor were analysed by Scatchard plot. $\mathrm{a}-\mathrm{b}, \mathrm{b}-\mathrm{c} ; \mathrm{P}<0.001 ;{ }^{\mathrm{a}-c} ; \mathrm{P}<0.01 ; \mathrm{d}-\mathrm{e} ; \mathrm{P}<0.05$. 
well demonstrated in bovine corpora lutea of pregnancy or mid-luteal stage using radioligand binding test $[1,9]$ and immunohistochemical study [15], there is no information about EGF concentrations in bovine luteal tissues. In this study, the EGF concentrations were measured first with a RRA using human placenta. It is well known that TGF $\alpha$ shares sequence homology and a common receptor with EGF and other peptides of the EGF superfamily [22]. In our RRA system, hTGF $\alpha$ inhibited the 125I-labelled rEGF from binding to human placenta membrane with a crossreactivity of $35.7 \%$ to rEGF (Fig. 1). Furthermore, since TGF $\alpha$ has been recently detected in bovine corpora lutea by immunocytochemical staining [23], what we measured might be the concentrations of EGF/EGF superfamily. In contrast with the highest concentration of EGF at mid-luteal phase, the affinity of EGF receptor of bovine corpus luteum decreased significantly from early to mid-luteal stage $(\mathrm{P}<0.05$, Table 1). Furthermore, since the concentration of EGF receptor unchanged through all luteal stages (Bmax $=35.1-46.3 \mathrm{fmol} / \mathrm{mg}$ protein), the activity of EGF to modulate the corpus luteum function might be regulated both by the changes in EGF concentration and the affinity of its receptor.

Despite of a number of works, the physiological role of EGF in bovine corpus luteum is not well understood. A direct stimulatory action of EGF on proliferation has been well demonstrated in bovine granulosa cells [1] but not in luteal cells [1, 7, 8]. Since EGF stimulates prostaglandin (PG) production in canine kidney [24], human amnion [25] and decidual cells [26], it is possible that PG production in bovine corpus luteum is regulated by EGF. Furthermore, Budnik and Mukhopadhyay [9] showed that adenylate cyclase activity in bo- vine luteal cells is finely regulated by EGF. It may be, therefore, suspected that EGF modulates the hormone synthesis in corpus luteum. Further studies are needed to clarify these points.

In this study, we demonstrated the existence of EGF in bovine corpus luteum during estrous cycle. But the site of origin for the production of luteal EGF is not known. Recently, Kennedy et al. [27] have detected using reverse transcription-polymerase chain reaction (RT-PCR) that transcripts for EGF, TGF $\alpha$, amphiregulin and heparin bindingEGF in porcine corpora lutea at day 4,10 and 20 of the estrous cycle, although any positive reaction in an immunocytochemical study using an antiserum raised against recombinant pig EGF could not be demonstrated in porcine corpora lutea by the same research team [28]. They suggested that luteal function may be subject to regulation by members of EGF family acting in an autocrine or paracrine manner. EGF synthesis in bovine corpus luteum could be demonstrated by more sensitive techniques such as RT-PCR. These studies are in progress.

\section{Acknowledgments}

We thank Dr. Y. Ibuki for supplying human placenta, and Dr. K. Niwa and Dr. L. R. Abeydeera for critical reading this manuscript and valuable discussion. A portion of this study was supported by a Grant-in-Aid from the Ministry of Education, Science and Culture of Japan (no.05806039), by a Grant-in-Aid (Bio Media Program: BMP-94-VI-3-1) from Ministry of Agriculture, Forestry and Fishery of Japan, and by Sanyo-Houso Foundation, Okayama, Japan.

\section{References}

1. Vlodavsky I, Brown KD, Gospodarowicz D. A comparison of the binding of epidermal growth factor to cultured granulosa and luteal cells. J Biol Chem 1978; 253: 3744-3750.

2. Carpenter G, Cohen S. Epidermal growth factor. Annu Rev Biochem 1979; 48: 193-216.

3. Gospodarowicz D, Bialecki H. Fibroblast and epidermal growth factors are mitogenic agents for cultured granulosa cells of rodent, porcine and human origin. Endocrinology 1979; 104: 757-764.

4. Bendell JJ, Dorrington JH. Epidermal growth fac- tor influences growth and differentiation of rat granulosa cells. Endocrinology 1990; 127: 533-540.

5. Jones PBC, Welsh TH Jr, Hsueh A. Regulation of ovarian progestin production by epidermal growth factor in cultured rat granulosa cells. J Biol Chem 1982; 257: 11268-11273.

6. Mondschein JS, Schomberg DW. Growth factors modulate gonadotropin receptor induction in granulosa cells cultures. Science 1981; 211: 11791180.

7. Gospodarowicz D, Ill CR, Birdwell CR. Effects of 
fibroblast and epidermal growth factors on ovarian cell proliferation in vitro: I. Characterization of the response of granulosa cells to FGF and EGF. Endocrinology 1977; 100: 1108-1120.

8. Gospodarowicz D, Ill CR, Birdwell CR. Effects of fibroblast and epidermal growth factors on ovarian cell proliferation in vitro: II. Proliferative response of luteal cells to FGF but not EGF. Endocrinology 1977; 100: 1121-1128.

9. Budnik LT, Mukhopadhyay AK. Epidermal growth factor, a modulator of luteal adenylate cyclase. J Biol Chem 1991; 266: 13908-13913.

10. Schams D, Kruip ThAM, Koll R. Oxytocin determination in steroid producing tissues and in vitro production in ovarian follicles. Acta Endocrinol 1985; 109: 530-536.

11. Milvae RA, Hansel W. Prostacyclin, prostaglandin F2 $\alpha$ and progesterone production by bovine luteal cells during the estrous cycle. Biol Reprod 1983; 29: 1063-1068.

12. Rodgers RJ, Mitchell MD, Simpson ER. Secretion of progesterone and prosta-glandins by cells of bovine corpora lutea from three stages of the luteal phase. J Endocrinol 1988; 118: 121-126.

13. Okuda K, Miyamoto A, Sauerwein H, Schweigert FJ, Schams D. Evidence for oxytocin receptors in cultured bovine luteal cells. Biol Reprod 1992; 46: 1001-1006.

14. Rao CV, Estergreen VL, Carman FR Jr. Receptors for gonadotrophin and prostaglandin F $2 \alpha$ in bovine corpora lutea of early, mid and late luteal phase. Acta Endocrinol 1979; 91: 529-537.

15. Chegini N, Lei ZM, Rao CV. Light and electron microscope immunocytochemical localization of epidermal growth factor receptors in bovine corpora lutea of pregnancy. In: Anne $\mathrm{N}$ Hirshfield (ed.), Growth factors and the ovary. New York and London: Plenum Press; 1989: 213-220.

16. Ireland JJ, Murphee RL, Coulson PB. Accuracy of predicting stages of bovine estrous cycle by gross appearance of the corpus luteum. J Dairy Sci 1980; 63: $155-160$.

17. Okuda K, Kito S, Sumi N, Sato K. Study of the central cavity in the bovine corpus luteum. Vet Rec 1988; 123: 180-183.

18. Savage CR, Cohen S. Epidermal growth factor and a new derivative: rapid isolation procedures and biological and chemical characterization. J Biol Chem 1972; 247: 7609-7611.

19. Lowry OH, Rosenbrough NL, Farr AL, Randall RJ. Protein measurements with the Folin phenol reagent. J Biol Chem 1951; 193: 265-275.

20. Thorell JI, Johansson BG. Enzymatic iodination of polypeptides with ${ }^{125}$ I to high specific activity. Biochim Biophys Acta 1971; 251: 363-369.

21. Scatchard G. The attractions of proteins for small molecular and ions. Ann NY Acad Sci 1949; 51: 660-673.

22. Carpenter G, Wahl MI. The epidermal growth factor family. In: Sporn MB, Roberts AB (eds.), Handbook of Experimental Pharmacology. Peptide Growth Factors and Their Receptors I. Berlin and Heidelberg: Springer-Verlag; vol.95/I: 69-171.

23. Lobb DK, Dorrington JH. Transforming growth factor- $\alpha$ : Identification in bovine corpus luteum by immunohistochemistry and northern blot analysis. Reprod Fertil Dev 1993; 5: 523-529.

24. Levine L, Hassid A. Epidermal growth factor stimulates prostaglandin biosynthesis by canine kidney (MDCK) cells. Biochem Biophys Res Commun 1977; 76: 1181-1187.

25. Mitchell MD. Epidermal growth factor actions on arachidonic acid metabolism in human amnion cells. Biochim Biophys Acta 1987; 928: 240-242.

26. Mitchell MD. The regulation of decidual prostaglandin biosynthesis by growth factors, phorbol esters, and calcium. Biol Reprod 1991; 44: 871-874.

27. Kennedy TG, Brown KD, Vaughan TJ. Expression of the epidermal growth factor receptor and its ligands in porcine corpora lutea. Endocrinology 1993; 132: 1857-1859.

28. Vaughan TJ, Pascall JC, James PS, Brown KD. Expression of epidermal growth factor and its mRNA in pig kidney, pancreas and other tissues. Biochem J 1991; 279: 315-318. 